\title{
A Study about Pork Farm in Surakarta as Export Commodity
}

\author{
Naufal Rhyo Ichwanda, Wilyam Lie \& Septyanto Galan Prakoso \\ Universitas Sebelas Maret
}

\begin{abstract}
ABSTRAK
Pork as one of the most consumed meat in the global food market is considered an important commodity in international trade. In Asia, especially East Asia and Southeast Asia, pork is considered as important in food culture even in the Moslem-majority countries like Indonesia and Malaysia. Although its commodity price is considered low in the international trade, the demand of pork is relatively stable. European Union is the current top exporter of pork, followed by United States and Canada, while China is the current top importer of porkfollowed by United States. Southeast Asia actually had a potential to develop its pork export but in reality, Southeast Asian countries still struggling to capitalize that opportunities. Between Southeast Asia countries only Thailand and Vietnam who are able to export their pork meat to other countries in a large scale. Therefore, we want to share the result of our qualitative study regarding this topic to enhance the knowledge about the condition and the prospect of this commodity and what barrier that hinder Southeast Asian countries from developing their pork market by using competitive advantage theory. The theory will be combined with pork farm in Surakarta, Indonesia as the study case. We hope the results of could contribute as reference to pork export development model in Southeast Asia.
\end{abstract}

Keywords: International trade, commodity, pork, strategy

Daging Babi yang banyak dikonsumsi di dunia mempunyai potensi besar untuk menjadi komoditas perdagangan internasional. Asia, khusunya Asia Tenggara dan Asia Timur memiliki budaya kuliner babi yang luas tak terkecuali di negara dengan mayoritas penduduk Muslim seperti Malaysia dan Indonesia. Walaupun harga komoditas ini tergolong rendah, namun permintaannya cukup stabil di perdagangan internasional. Eksportir terbesar sekara dipegang oleh Uni Eropa diikuti oleh Amerika Serikat dan Kanada. Sedangkan, importir terbesar dipegang oleh China diikuti oleh Amerika Serikat. Asia Tenggara sebenarnya memiliki potensi untuk mengembangkan ekspor babinya dan mengambil sebagian komoditas perdagangan internasional dari babi. Namun dalam kenyataannya hanya Thailand dan Vietnam yang mampu mengekspor daging babi mereka ke negara lain dalam skala besar. Negara lain masih belum mampu mengejar. Oleh karena itu, kami ingin membagikan hasil dari penelitian kualitatif kami terkait dengan topik ini untuk meningkatkan pengetahuan mengenai kondisi dan prospek dari komoditas ini serta tantangan apa saja yang menghalangi negara Asia Tenggara dalam mengembangkan komoditas ini dengan menggunakan teori keuntungan komparatif dan peternakan babi di Surakarta sebagai studi kasusnya. Hasil dari penelitian ini kami harapakan dapat digunakan sebagai referensi untuk mengembagkan eskpor babi di Asia Tenggara.

Kata-kata Kunci: Perdagangan Internasional, komoditas, babi, strategi 
Pork is often neglected by people as an export commodity. In spite of their trade value pork is inferior compared to other agricultural product such as corn, wheat, or soy. Pork is the second highest consumed meat in the world behind chicken. Asia has become one of the biggest markets of pork with China, Taiwan, and South Korea as the major consumer. Their total consumption per capita combined is more than 36 kilograms per capita which is among the top six of pork consumer (National Hog Famer 2018). Therefore, this market presents opportunity for other Asia country develop their pork production given their close geographic ties.

Indonesia is one of the countries that should capitalize this opportunity. But, the current production of pork is only sufficient to fulfill domestic demands. Pork ranked second most consumed meat in Indonesia with consumption per capita of 2.25 kilogram per capita (OECD 2018) However, this commodity barely developed to enter the international trade. Despite this condition, Indonesia still able to exports pork to Singapore, Vietnam and United Arab Emirates. The export value reached around \$59 million in 2016(Adam 2017). It is clear that if Indonesia intent to capitalize on this sector, they can play a bigger role in the global pork market.

Pork farm in Surakarta is considered a good example for general Indonesia condition because it is a multicultural city that has deep ties with pork itself. Pork was considered an inseparable part of culinary tradition in Surakarta. Pork mostly consumed by Chinese descendant in Surakarta along with other local people. However, as time goes by the condition of pork production in Surakarta changed. Some of the old pork farm have to move to the outer parts of Surakarta and deal with other consequences that follow.

This paper will try to figure the problem that hindering Indonesia pork export in general using the case of Surakarta in developing the pork commodity by analyzing the competitiveness of Indonesia. From this research, we hope that our conclusion could become a further reference and recommendation for the development of pork industry in Indonesia. The success of the efforts could be measured by using certain parameters such as the increase of investment in this commodity production sector, the increase of production in this sector, and the increase of amount and value of pig export from Indonesia to other country.

\section{Framework of Analysis}

In order to answer the underlying question of this research, we use Competitive advantage as the basic theory. Competitive advantage examines the efforts to seek competitive positions that are advantageous in an industry and a fundamental arena where competition will take place (Porter 1993). Competitive advantage basically grows from the value or benefits that can be created by a company or country for its buyers that are more than the costs that must be incurred by companies or countries in creating it (Porter 1993). In this paper the author uses competitive advantage strategy as a basic framework in conducting a competitive advantage analysis of the trade of pigs in Surakarta City. Competitive advantage strategy that includes the country's ability to compete in international trade, assesses five factors that determine each other's competition, including: Competitor countries, consumers, producers, substitution products, and new competitors. The structure of competition that is created causes 
the state to be able to use its strategy so that sustainability in the international trade system is maintained.

As a systematic analysis tool, the author also uses the value chain to help solve existing problems related to pig trade in Surakarta and Indonesia in general. Value chain itself is one source of competitive advantage and consists of nine generic activity groups which include company infrastructure, human resource management, technology development, purchasing, logistics input, operations, logistics output, marketing and sales, and company services. Through this value chain the author will analyze the role of the state in conducting competitive advantage in the pig trade sector. So that by carrying out the analysis using the concept above, it is expected that Indonesia and the City of Surakarta will be able to become players who have competitiveness in the international pork trade. Mixed research type whereas the quantitative study methodology will be mixed with qualitative study methodology to illustrate and try to explain the potent of pork trade in Southeast Asia.

In this study, researchers conducted interviews with the kir master of the Department of Agriculture and Engagement of Surakarta City. Kir master is someone who responsible of the slaughtering house in that department. This study also employs literature study by collecting data obtained from library sources such as books, journals, or other scientific sources. Some book literature and other scientific sources obtained from internet or printed sources also used. Last but not least, field observation to some the pork farms around Surakarta also done as one of the important steps in this research.

\section{Indonesia Pork Competitiveness}

Before entering international pork market, we must analyze the competitiveness of Indonesia in term of pork commodity first. By analyzing five competitive advantage indicators of Indonesia to enter the pork market in international trade we could conclude what sector must fixed or further enhanced by government or other stakeholders.

The first factor to considered is competitor countries, this factor account for all countries that competing in the commodity market. Competing country is all country that exporting pork to the international market. In line with that description we will then look at the biggest exporter and nearest competitor by geographical position for Indonesia pork trade.

The international pork market is now controlled by European Union countries combined with $\$ 8.4$ Billion export value on 2017 securing $40 \%$ of world pork export (National Hog Famer, 2018). United States followed European Union with value of export around $\$ 5.94$ billion and the third is Canada with $\$ 2.78$ billion export value on the same year (National Hog Famer, 2018). European Union and United States is included among the highest countries of pork consumption per capita with 40.7 kilogram and 29,1 kilograms respectively (National Hog Famer 2018). With the high rate of consumption, they still managed to expand their production to international trade. The condition of Asian countries is slightly different than Western countries. Asian countries such as Japan, China, and South Korea is also among the largest producer of pork in the world. But they still struggled to fulfill their domestic market demand. They still import a lot of pork from other countries in order to fill their deficit. China, Japan, and South Korea import of pork if combined is contributing almost 60\% 
of world pork import (National Hog Famer 2018).

However, some countries in Asia are already able to expand their production to the international market. Some countries that already able to export are Vietnam, and Thailand. Thailand export amount is around 17.000 metric tons on 2016 (Strak, 2016). Meanwhile, Vietnam export is around 16.000 metric tons in 2016 (Ipsos, 2016). However, if that number compared to other exporter countries such as United States and European Union, their export is still far behind. Other than Vietnam and Thailand, pork from Southeast Asia region often prohibited to enter international market due to health issues such as the using of non-safe livestock food addition or disease.

The second factor, namely consumer focused on how the condition of pork consumption both locally and globally. Globally, pork is the highest consumed meat in the world. It beats beef, lambs, and others. Although there are some countries that do not consume pork at all, pork still dominated the meat consumption, around $40 \%$ of global meat consumption is consisted of pork. In Indonesia, consumption of pork is around 2.25 kilogram per capita on 2016, second highest after chicken (OECD 2018). If we compared to Malaysia, this number may seem pretty low, Malaysia consumed around 6.5 kilogram of pork per capita on 2016 (OECD 2018). The average number may seem lower but the total consumption may be higher due to the difference of total citizen in each of those countries. Actually, Indonesian people who consumed pork are not limited by ethnicity or religion. Local people especially who are non-Moslem also consumed it and there are some non-practicing Moslem who consumed it also. In Indonesia, pork was popular because of it is cheaper than beef but a bit more expensive than chicken. On local market pork is priced Rp 30.000 until Rp 50.000 per kilogram, it depends on which part of the pork that you buy (Hardjianto 2017). It is pretty different than beef price that ranged at more than $\mathrm{Rp} 100.000$ per $\mathrm{kg}$. Therefore, pork is preferable than beef for some people.

The third factor is production power, this factor is about the power of production sector in one country. The producing activities in Indonesia vary from one region and another, but in case of Surakarta he production output is getting lower day by day. From 2014-2016 there are 6\% of decrease in pork production in Surakarta. This decrease is mostly caused by closure of pork farm (UPT RPH Surakarta 2017). The most frequent case is the moving of farm to other region because of the regulation in Surakarta itself prohibiting to have a large livestock farm especially pork inside the administrative territory of Surakarta. Livestock farm that allowed inside the administrative territory of Surakarta must be a farm that has less than twenty animals. Therefore, the farms had to be moved because of the increasing density in urban area. However, in the new relocated place, another problem emerged. Not all rural area is welcome to relocation of the pork. People in the new area are often feels disturbed by the waste produced by pork farm. This unclear situation sometimes led the closure of the farm or replacement of pork into another livestock. The condition is preventing development of pork production into international market.

Despite of that condition in Surakarta, the production of pork nationally can potentially be increased to surpassed the national consumption. In period of 2015-2016, surakarta recorded an increase 3.6\% of national pig production (Adam 2017). However, the increase is lower if compared to 2014-2015 increase which was 9.2\% (Adam 2017). This happen because other region has a better supportive condition for pork, but the condition in Surakarta is hindered by the problem of pork farm in urban area. 
In 2016, from total 342.346 metric tons of pork production, $9 \%$ of it can be exported to Singapore (Adam 2017). This output means pork from Indonesia has good quality since we know Singapore have strict rules regarding health issues and may pass other countries standard. If we look from the pork farm in Indonesia, pork was classified into different categories. Pork that has weight above $150-200 \mathrm{~kg}$ is prioritized to be delivered into the company who run the export of pork from Indonesia to Singapore (Hardjianto 2017). Meanwhile, pork that weight less than that category is distributed for local consumption.

Other condition in Indonesia pork farm that needs to be highlighted is the system of the pork farming itself. In Indonesia, pork farms are usually owned by individual owner. This individual owner system limited the maximal number of pork in one farm to 200 livestock each farm(Adam, 2017). There is only one company that invested in this sector which is PT Indotirta Suaka, as the exporter from Indonesia to Singapore. This company mostly only buy from local farmers in Indonesia mostly from Riau before exported the pork to Singapore. This condition is different if we compared them with Charoen Phokpand Food, a pork producer company from Thailand (Farm Journal's Pork 2011). They produce their own pork so they can fully control the production of their products (Farm Journal's Pork 2011). Meanwhile, substituting pork with other product is something that nearly hard to do. Pork as a food sources already has a specific market and specific usage in culinary. If compared to other meat product, pork also cannot be replaced since it has a different price range than another livestock meat. So, it is clear that pork has no product competitor that can threaten its consumption.

The last factor is new competitor, this factor focuses on the coming threat from the emerging of another competitor besides the existing competitor that have already been analyzed. However, the new competitor in pork trade is the old countries who hold a small portion in pork trade and started to develop pork industries as its export commodity. The example of the new competitor is New Zealand and Malaysia. New Zealand currently tried to develop their pork production to enter international market. Their new cooperation with Australia in term of exporting pork is highlighting significant progress of their pork export (Hutching 2016). On the other side, Malaysia mark their progress of pork trade by delivering their first pork export into Singapore after being banned because of previous pork disease outbreak (Strait Times 2016).

\section{Value Chain Analysis}

To measure the competitive advantage possessed by Indonesia in the pig trade in Asia, the authors then define a value chain to compete in pig trading activities. Each value activity that is the basis of the value chain is divided into several generic group activities, and in this paper, we will use supporting generic group activities, where some things become indicators:

The first indicator is Infrastructure, Pig farms in Surakarta has followed the standardization of infrastructure and procedures established at national and international levels, in this case pig farms in Surakarta must be able to apply the value chain where infrastructure is included. Some Standardization of Infrastructure and Procedures that have been implemented including (1) Waste processing, the position of the pig pen must be lower than any other animal so that the waste is not mixed with each other, 
because if the waste is mixed together it is feared that the stock would be vulnerable to viruses and diseases. In addition, the existence of a waste treatment system before being discharged into the water channel makes pig farms in Surakarta have a competitive advantage in terms of health, (2) Pen, in caring for pigs must not be overloaded, in this case there are some regulations regarding the ratio between ideal enclosure area and ideal number of pigs. Generally, each pig needs at least $4 \mathrm{~m}^{2}$ of pen area, this is due to the air circulation management and to maintain the level of density. In addition, for the freshness of pigs, it is recommended to use a battery pen where one pen is only owned by one pig to keep pigs away from stressful behavior that can affect the health of their health. Pens must also be routinely cleaned once a month using chlorine so that it can be sterilized, (3) Butchering, must include several steps such as pig heart stabbing, separation of innards from the body, separation of head to tail until becoming carcass, cleaning and sterilization of the cutting environment, and the last is boiling to remove hair from a pig, (4) Animal Healthy Procedure, before being marketed and slaughtered, pig from the farm in Surakarta will be tested with ante-mortem and post-mortem techniques. Ante-mortem which includes examination of pigs before slaughter and post-mortem which includes examination after slaughter of pigs. Both of these are carried out to ensure that the pork quality is in accordance with the standards set by the authorized agencies, (5) Work Safety Procedure, the work safety procedures is practiced carefully by pig farms in Surakarta to minimize workplace accidents by means of a series of agreed rules. This procedure includes, the use of strong footwear such as rubber boots, safety suits, health masks, and using a special knife during the killing process to avoid accidents caused by negligence of workers. And finally, each worker must also clean himself before and after cutting pigs.

The second indicator is Human Resource Management, human resource management consists of several activities which include recruitment, acceptance, training, development, and compensation for all types of labor (Porter 1993). Human resource management practiced by the pig farm association in Surakarta is in accordance to the principle set by the Surakarta Livestock and Fisheries authorities. Even though workers are voluntarily recruited but in acceptance, they must have experience in handling livestock. After the workers are selected, they will receive training within 6 months to 1 year in order to learn several things related to animal handling and welfare, insemination, pen sanitation management, and health and worker protection.

In addition to the workers, there are other human resources who serve as support systems of workers such as veterinarians and livestock supervisors. Unlike the recruitment of workers, to become veterinarians and livestock supervisors in pig farms in Surakarta, it is obligatory to have education related to the tasks to be carried out, in this case the veterinarian must be a graduate of veterinary medicine and for livestock supervisors preferably graduates from agriculture or animal husbandry. Despite having several differences, in terms of the development and compensation of work accidents, these three stakeholders get the same portion. To increase the quality of workers who do not have adequate education scholarships will be given in the field of animal husbandry or agriculture to support the human resources development program, so that the competitive is maintained at a high level (Hardjianto 2017).

The third factor is Technology Development, in fulfilling value activities to achieve competitive excellence, pig farmers in Surakarta adopted Good Animal Husbandry Practices which regulates matters relating to standardized animal husbandry processing systems for all types of livestock, such as: (1) Drinking Water, drinking water that 
is given to livestock is carefully selected. The drinking water provided must be feasible and processed first. The water quality must also be checked regularly to minimize contamination of drinking water from metals or harmful bacteria that can endanger livestock and those who consume them, (2) Pen, the pen must have sufficient electricity and water supply, not located close to the river or water, and if the pen is already standing in the area near the water then the pen owner must have a mitigation management for example during flood such as using a catchment system or water overflow storage technique. The pen must also have fence and ventilation and is designed in such a way that it is easy to clean, (3) Animal Healthy, every animal that comes in the form of seeds or is ready to harvest must be qualified and must be separated from other livestock, this is due to minimizing stress risks. In addition, vaccination must be applied to livestock as well as regular health checks by veterinarians.

\section{Conclusion}

The implementation of supporting activities in the development of pig trade in Indonesia when viewed from the City of Surakarta can be analyzed as having better competitive advantages over other countries in both Southeast Asia and throughout Asia. But the national spotlight is that support activities are maximized only by a number of supporting centers for pig farming in Indonesia, one of which is the City of Surakarta. For example, in Tana Toraja Regency, the last survey in 2011 stated that there was a maintenance of traditional pigs without $50 \%$ of modern technology assistance, $45 \%$ semi-intensive, and $5 \%$ intensive (Soewadi \& Talib 2015). This can simply illustrate that not all pig farms operation development in Indonesia are carried out intensively.

The lack of equal distribution of pig farming can be one of the obstacles in achieving the competitive advantage. For this reason, there needs to be cooperation between the government, breeders, and the community in terms of utilizing supporting elements such as policies and on increase the productivity of pig farms in Indonesia. It is clear that pork has big value and opportunity as highlighted by value chain theory. As one of the biggest meat markets potential in Asian countries especially in east and southeast countries, pork can be one of the source for economic development in Indonesia. Now it is time to government, people, and other actor to see and realize the opportunity of pork to become the export commodities in Indonesia without being discriminated.

During the conduct of this research there are some difficulties regarding this study. First, it is hard to get the data of pork in Indonesia, either the production, consumption, or distribution. There is only limited source from the Ministry of Agriculture in national level that only cover the major things nationally and not region-specific information. When we try to find the detailed one on regional level, not all regional government published pork data, even if they have pork farm inside their territory. Regional government often only published the data of beef, lamb, and chicken, without pork. The permission and clearance to conduct research about pork is complicated especially in the government sector. Further study needed to find out why this is happening.The second is due to different standard of the pork farm in each region. As example form Nusa Tenggara and Tana Toraja that almost 50\% were traditional pig farm.

Despite the high production of pork in Asian countries especially in East and Southeast Asia, Asian countries still struggled to developed pork to become one of its export 
commodities. They are still unable to meet the demand of their national consumption. Their production is not as efficient as other pork producing countries. However, Indonesia could benefit from this phenomenon by filling the gap by developing their pork export to other pork consuming countries.

To conclude, the controversy surrounding pork either as a food or even as an export commodity is a long-standing debate. Despite the status of pork itself, the demand in the domestic sector, especially around the city of Surakarta, is still high. The pork farm in Surakarta is considered as a good example of Indonesia condition because it is a multicultural city that has deep link with pork itself. Realizing this potential, a more excessive effort is needed to maximize the potential of pork as an export commodity. However, a lot of researches need to be conducted, especially in order to set the standard and improving the quality of the local pork itself. Another factor which is still need to be considered is the competitor countries, as they already have established market, and have fulfilled the demand from the customers for a long time ago hence they have a better institution and regulation.

While there are obstacles toward the objectives, as long as the consumers and the producers of pork still shows significant demand, there is potential for the market to grow. Another problem may arise if the quality of the product itself is not controlled; this can be prevented by correctly implementing the content of value chain into the production steps and phases. By ensuring the quality of the product, the realization of pork as an export commodity from Indonesia to Asian market is both viable and achievable.

\section{References}

\section{Books}

Hardjianto. 2017. Keadaan Peternakan Babi di Kota Surakarta. W. Lie, \& N. Rhyo, Interviewers

Porter, M. E. 1993. Keunggulan Bersaing: Menciptakan dan Mempertahankan Kinerja Unggul. Jakarta: Erlangga.

Soewadi, B. D., \& Talib, C. 2015. Pengembangan Ternak Babi Lokal di Indonesia. WARTAZOA, 40.

\section{Annual Report}

UPT RPH. 2017. Data Pemotongan Hewan di Surakarta. Surakarta: Dinas Pertanian, Ketahanan Pangan dan Perikanan Kota Surakarta.

\section{Online Article}

Adam, A. 2017. Tawa Putin dan Ekspor-Impor Daging Babi Indonesia [Online] in https://tirto.id/tawa-putin-dan-ekspor-impor-daging-babi-indonesia-cyBp accessed August 22, 2018. 
Farm Journal's Pork. 2011. Thailands Swine Industry: Moving forward. [Online] in https://www.porkbusiness.com/article/thailands-swine-industry-movingforward Retrieved September 5, 2018

Hutching, G. 2018. New Zealand pork soon to be on Australian tables [Online] in https://www.stuff.co.nz/business/farming/102022069/new-zealand-pork-soonto-be-on-australian-tables Retrieved September 5, 2018,

National Hog Farm. 2018. Who made the Global Mega Producer list this year? [Online] in https://www.nationalhogfarmer.com/business/who-made-globalmega-producer-list-year Retrieved August 20, 2018.

OECD. 2018. OECD Meat Consumption. [Online] in https://data.oecd.org/agroutput/ meat-consumption.htm Retrieved August 26, 2018

Others, N. R. 2017. The Vietnam Swine Market [Online] In https://www.ipsos.com/ sites/default/files/ct/publication/documents/2017-09/The-Vietnam-SwineMarket.pdf Retrieved September 1, 2018

Straits Times. 2017. First live pigs from Malaysia in 18 years. [Online] in https:// www.straitstimes.com/singapore/first-live-pigs-from-malaysia-in-18-years Retrieved September 3, 2018

Strak, J. 2016. Thailand: A tiger cub ready to leap [Online] in https://www. pigprogress.net/Home/General/2016/12/Thailand-A-tiger-cub-ready-to-leap74446E/ Retrieved September 1, 2018 
A Study about Pork Farm in Surakarta as Export Commodity 